症 例

ガス産生肝膿瘍に対し経皮経肝的ドレナージ後に外科的切除を適用した 1 例

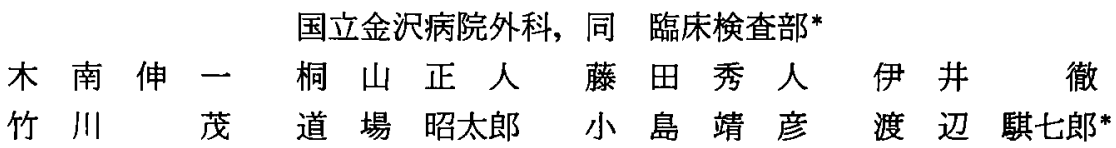

症例は55歳女性で，熱発，全身倊急感，意識障害を主訴として緊急入院した．未治療 の楉尿病以外に特記すべき既往歴はない. 腹部超音波検查扝よび腹部 CTにて, 肝 S7, 8 に直径 $12 \mathrm{~cm}$ に及ぶガス産生肝膿瘍を認め, 直ちに経皮経肝的肝澧灌ドレナージを行っ た. 膿の細菌培養から Klebsiella が検出された。非ケトン性高浸透圧性昏睡, 急性循環 不全, DIC を併発していた. 抗生物質投与, 朖瘍腔洗净, 高カロリー輸夜等によって, 全身状態の改善と膿場腔の縮小が得られたが，肉芽の増生を伴う器質化した不規則な膿 瘍が残存した。難治性肝膿瘍と考え, 68 日目に右開胸開腹にて肝 S7, 8 の部分切除術を行 つた。切除標本には不規則かつ慢性の膿瘍像が認められ，膿瘍の培養にて Staphyrococcus epidermidis が検出された。術後経過は良好で, 術後39日目に退院した。難治性肝膿 瘍に対する外科的切除は，根治的でかつ入院期間の短縮にもつながる有効な治療法のひ とつと考えられた。

索引用語：化膿性肝膿湯, 経皮経肝的朖瘍ドレナージ, 肝切除術

はじめに

化膿性肝膿瘍の治療法として, かつては外科的切開 排膿術が行われていたが，予後は不良であっだ21。そ の後, 画像診断が進歩し, 抗生物質の開発と, 経皮経 肝的膿場ドレナージ (percutaneous transhepatic abscess drainage：PTAD) の登場によって, 治療成績の 向上が認められるようになった ${ }^{3 / 4)}$. 肝膿煌に対する肝 切除の適用は, 多発性胆管炎性肝膿瘍などに試みられ ているがラーブ,一般的ではない.しかし肝膿煌の病態に よっては,ドレナージのみでは不十分で，治癋を得る ため，また入院期間の短縮を図るために，肝切除が必 要な場合もある。

今回われわれは，敗血症性ショックと，非ケトン性 高浸透圧性糖尿病性昏睡を合併した，直径 $12 \mathrm{~cm} に 及$ ふガス産生化膿性肝膿瘍症例を経験した。この症例に 対し,まず PTAD を行い, 良好な排膿, 全身状態の改 善を得たのち, 難治性となった膿瘍部分の肝部分切除 術を施行し, 良好な結果が得られたので, 若干の文献 的考察を加えて報告する.

1999年 5 月 6 日受付 2000 年 3 月 21 日採用

\section{症例}

症例：55歳, 女性.

主訴: 発熱, 侉急感, 体重隇少, 意識障害.

家族歴：特記すべき事なし.

既往歴：精尿病に痽患するも放置.

現病歴：1997年11月10日より39 Cの発熱と全身倦急 感が出現. 近医にて感冒の診断で治療を受けるも軽快 せず, 約半月で $4 \mathrm{~kg}$ の体重隇少も認めた. 11月27日に は食事摂取が困難となり, その後意識障害も出現し, 翌28日救急車にて当院へ搬送され緊急入院した。

入院時現症：身長 $151 \mathrm{~cm}$, 体重 $49 \mathrm{~kg}$. 体温 $38.6^{\circ} \mathrm{C}$, 心拍数 $126 / \mathrm{min}$., 血圧 $108 / 70 \mathrm{mmHg}$. 傾眠状態で, 眼 瞼, 眼球結膜は負血, 黄疸なく, 腹部は平坦・軟て腫 㾇は触知しなかった。

入院時検查所見：血液生化学検查では, 白血球 $14300 / \mathrm{mm}^{3}, \mathrm{CRP} 29.8 \mathrm{mg} / \mathrm{dl}$ と強い炎症所見を示し, さらに高度の肝機能障害と, 血糖值 $638 \mathrm{mg} / \mathrm{dl}$, 血中ケ トン $6002 \mathrm{~mol} / \mathrm{l}, \mathrm{Na} 166 \mathrm{mEq} / \mathrm{l}, \mathrm{Cl} 28 \mathrm{Eq} / 1, \mathrm{BUN} 38.4$ $\mathrm{mg} / \mathrm{dl}$ と, 非ケトン性高血糖, 著明な脱水・電解質異 常を認めた (表 1 ).

腹部単純 $\mathrm{X}$ 線所見 : 右横隔膜の挙上と, その下方に 不均一なガス像を認めた（図 1$)$. 
表 1 入院時検查所見

\begin{tabular}{|c|c|c|c|c|c|c|c|c|}
\hline WBC & 14300 & $/ \mathrm{mm}^{3}$ & T.Bil & 0.4 & $\mathrm{mg} / \mathrm{dl}$ & LAP & 127 & IU/I \\
\hline Seg & 59.5 & $*$ & TP & 6.2 & $g / d l$ & ChE & 60 & IU/I \\
\hline Band & 33.5 & $\%$ & Alb & 39.1 & $\%$ & amylase & 19 & IU/I \\
\hline Lym & 2.5 & $\%$ & $\alpha 1$ & 6 & \% & CPK & 53 & IU/I \\
\hline Mono & 0 & $x$ & $\alpha 2$ & 20.8 & $x$ & $\mathrm{Na}$ & 166 & $\mathrm{mEq} / \mathrm{I}$ \\
\hline Eosin & 0 & $x$ & $B$ & 7.5 & $x$ & $K$ & 4.9 & $\mathrm{mEq} / \mathrm{I}$ \\
\hline Baso & 0 & $x$ & $r$ & 26.6 & $\%$ & $\mathrm{Cl}$ & 128 & $\mathrm{mEq} / \mathrm{I}$ \\
\hline Metamyel & 3.5 & $x$ & $\mathrm{ZTT}$ & 6.5 & $\mathbf{U}$ & BUN & 38.4 & $\mathrm{mg} / \mathrm{dl}$ \\
\hline Myel & 1 & $x$ & $\pi T$ & 4.5 & u & $\mathrm{Cr}$ & 1.2 & $\mathrm{mg} / \mathrm{dl}$ \\
\hline $\mathrm{RBC}$ & $462 \times 10^{4}$ & $/ \mathrm{mm}^{3}$ & AST & 209 & $1 \mathrm{U} / 1$ & $\mathrm{Ca}$ & 9.2 & $\mathrm{mg} / \mathrm{dl}$ \\
\hline $\mathrm{Hb}$ & 13.5 & $g / d l$ & ALT & 128 & IU $/ 1$ & $P$ & 2.6 & $\mathrm{mg} / \mathrm{dl}$ \\
\hline Hct & 41 & $\%$ & $\mathrm{LDH}$ & 1376 & $1 U / 1$ & UA & 7.3 & $\mathrm{mg} / \mathrm{dl}$ \\
\hline Plt & $18.2 \times 10^{4}$ & $/ \mathrm{mm}^{3}$ & ALP & 590 & IU/I & BS & 638 & $\mathrm{mg} / \mathrm{dl}$ \\
\hline CPR & 29.8 & $\mathrm{mg} / \mathrm{dl}$ & $r$-GTP & 278 & IU/I & 血中ケトン & 6002 & $\mu \mathrm{mol} / \mathrm{I}$ \\
\hline
\end{tabular}

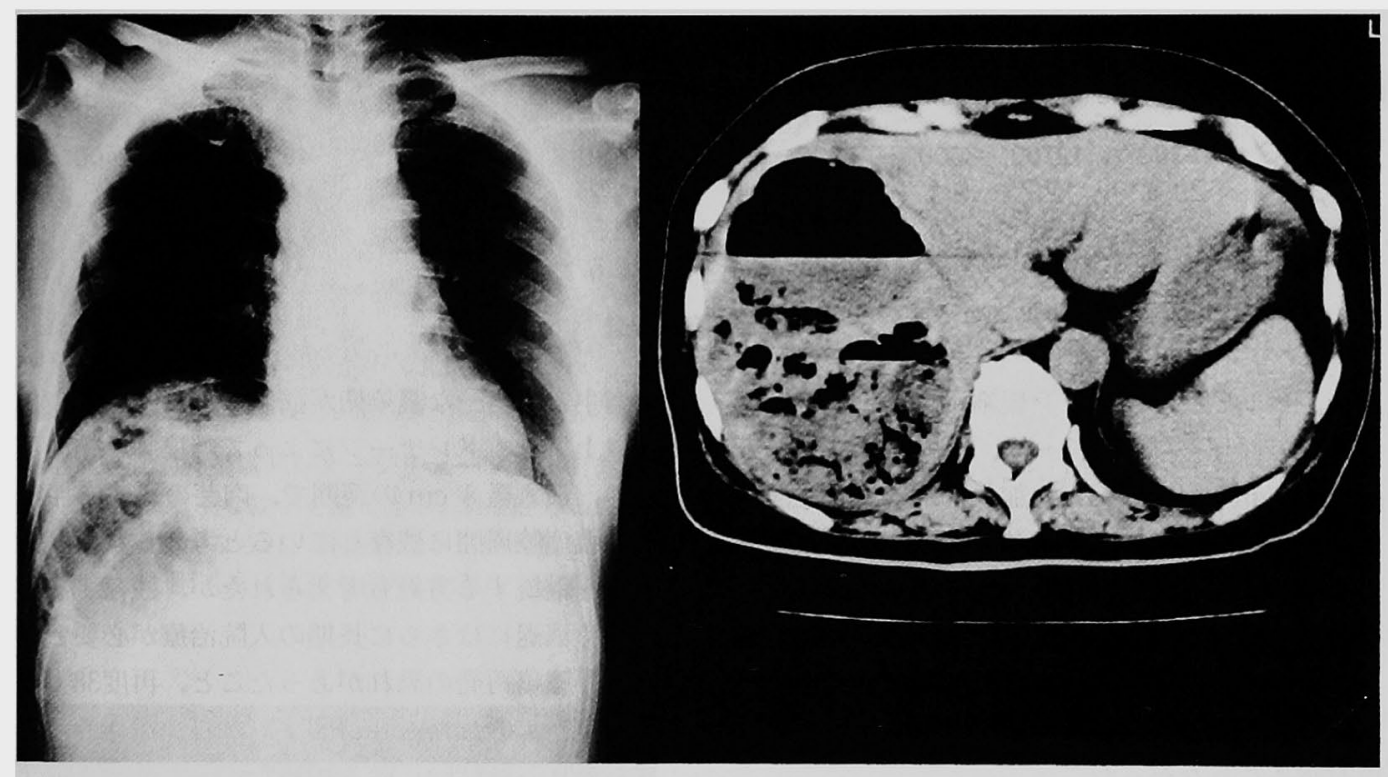

図 1 入院時胸部単純 X 線像および腹部 CT 像：単純 X 線像で, 右横隔膜の挙上と,その下方に不均一なガス像を 認める. CT では, 肝右葉に, 内部に不均一な燷死性物質と, 液体・ガスを賖留する, 境界明瞙な裹胞性の占拠 性病変を認める.

腹部超音波所見 : 肝右葉に内部不均一な高エコー域 が描出され, 内部に気体を含む肝占居性病変の存在が 疑われた。

腹部 CT 所見：肝右葉の S7 - 8 由来と考えられる, 境界明瞭で, 内部に不均一な壊死性物質と液体・ガス の貯留を認める, 最大径 $12 \mathrm{~cm}$ の亳胞性の占居性病変 を認めた（図 1 ).

以上より, 肝 S7 - 8 由来の肝膿瘍, 敗血症, 非ヶト ン性高浸透圧性糖尿病性昏睡と診断し, 直ちに PTAD を行った。

PTAD：右側腹部第 9 肋間よりエコーガイド下に
膿瘍を穿刺し，9Frバルン付きドレナージチューブを 留置したところ, 悪臭のある気体と黄緑色の膿汁の排 泄が大量に認められた。膿汁の細菌培養では, Klebsiella が検出された，嫌気性菌は検出されなかった。

入院後臨床経過：鎖骨下穿刺にて中心静脈カテーテ ルを挿入し, half saline の輸液とインスリンの持続点 滴静注, 抗生物質 (SBT/CPZ), 肝仳護剤の投与, 鎮 静剤の持続点滴を行った. 翌日には, 敗血症性ショッ クと DIC (disseminated intravascular coagulation) の併発を認めたため(血小板 $3.4 \times 10^{4} / \mathrm{mm}^{3}$, FDP28.4 $\mu \mathrm{g} / \mathrm{ml}$ ), dopamine, gabexate mesilate (FOY $\left.{ }^{\circledR}\right) の$ 


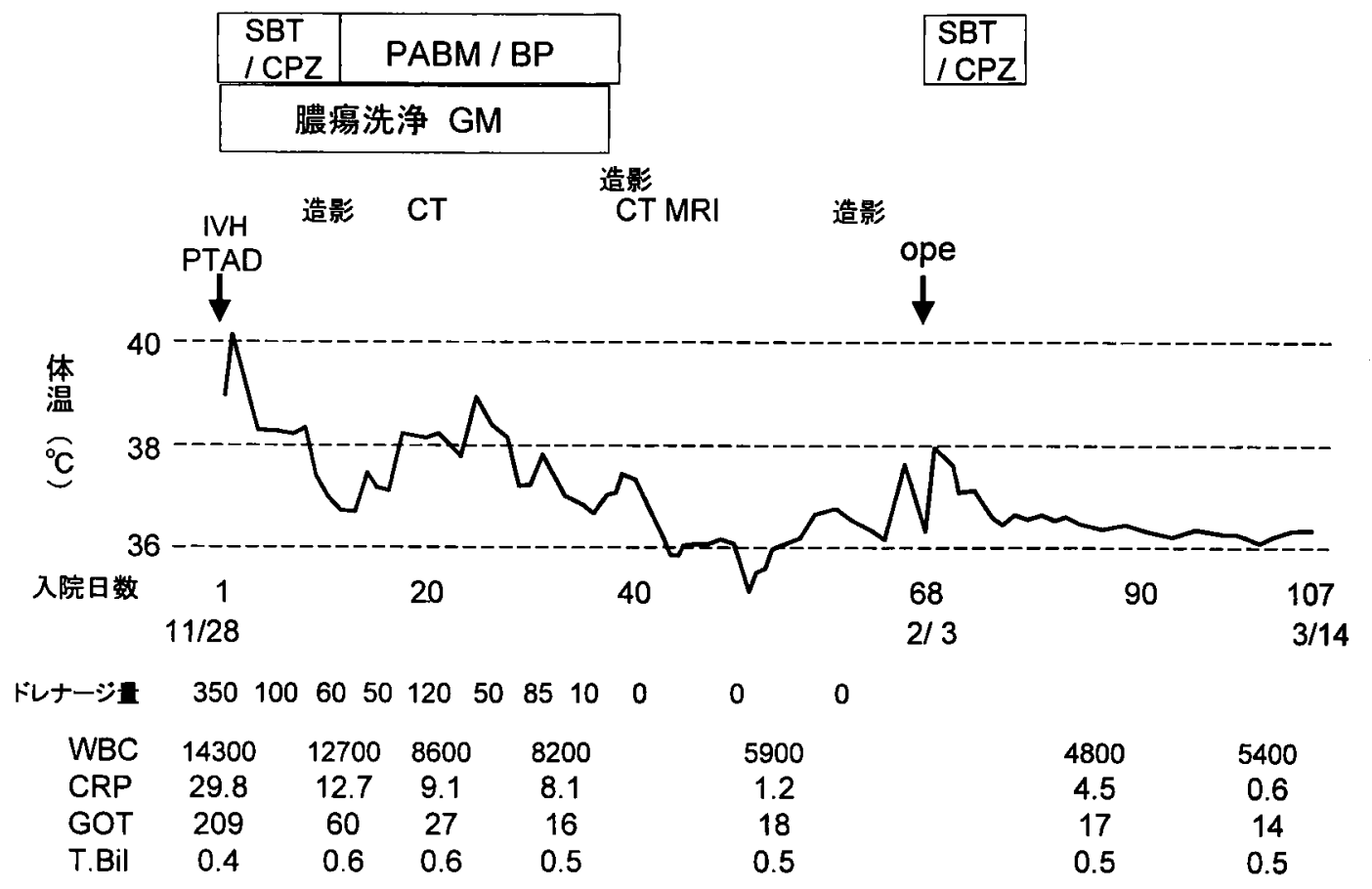

図 2 臨床経過

持続点滴, ヒト免疫グロブリン製風・AT III製剤・アル ブミン製剂の投与を行った。一方，肝膿瘍腔に対して は, gentamicin sulfate (GM) 加生食水による洗净を 行った.PTADチューブからの排膘は良好で, 入院後 10日目にはDIC から脱し，意識状態も正常に復した。 入院後30日目には熱発がなくなり，33日目にはPTAD からの排液はほとんど消失した(図 2 ).なお，胃内視 鏡, 注腸検査では異常所見はなく, 他の部位には細菌 感染巣が認められなかった。

PTAD チューブ造影所見：39日目の造影で, 膿劰腔 は著明に縮小していたが, 膿瘍腔と肝内胆管との間に 交通がみられ, 肝内胆管から総胆管・胆異まで描出さ れた。胆道系には, 拡張や狭窄, 結石などの異常は認 めなかった、ドレナージ効果は十分であると判断し， 胆道ドレナージの追加は行わなかった（図 3 ).

腹部 CT 所見：21日目の CT では, 肝ドーム下 S7・ 8 の膿瘍腔は直径 $3 \mathrm{~cm}$ まで著明に縮小したが，膿瘍 腔の周囲には境界不明瞭な low density area が認め られた.41日目の CT では, 更に膿瘍腔は縮小したが, 膿瘍腔周囲の low density areaは, 最大径 $8 \mathrm{~cm}$ の範 囲で遺残していた。なお，肝内胆管の拡張はなく，肝 内結石も認めなかった（図 4 ).

腹部血管造影所見：旰ドーム下 $\mathrm{S} 7 \cdot 8$ に，細かな血
管增生と不均一な濃染像が描出された.

以上より,ドレナージによって膿瑒腔は縮小したも のの, 最大径 $8 \mathrm{~cm}$ の範囲で, 肉芽の形成を伴う膿場 が，膿場腔周囲に残存していると考えられた。保存的 治療を継続する方針も考えられたが, 残存する病巣が 大きく消退にはさらに長期の入院治療が必要となるこ と, 肝膿瘍再発の恐れがあったこと, 再度 $38^{\circ} \mathrm{C}$ 以上の 発熱が認められたこと（図 2 ) から，保存的治療の限 界と考え, 肝切除に踏み切った。

手術所見：右第 8 助間にて開胸開腹し, 術中エコー で切除範囲を決定した後, CUSA を用いて肝 S7, 8 区 域の部分切除術を施行した。

切除標本所見：切除された肝の重量は64g,大きさ は9.0×6.5×2.4cm であった. 割面の所見では, 黄白 色の肉芽の増生を伴う, 器質化した大小不同・不規則 な膿瘍が広範囲に認められた(図 5 )。割面からの培養 で Staphyrococcus epidermidis が検出された.

病理組織学的所見：小円形細胞浸潤と肝組織の破壊 からなる慢性肝膿㾮の像が，広範かつ不規則に認めら れた．悪性腫瘍の合併は認めなかった（図6).

術後は胆汁漏出などの合併症もなく良好に経過し, 糖尿病も食事療法のみで管理可能となった。術後39日 目に軽快退院し, 現在まで再発の徴候を認めていない. 


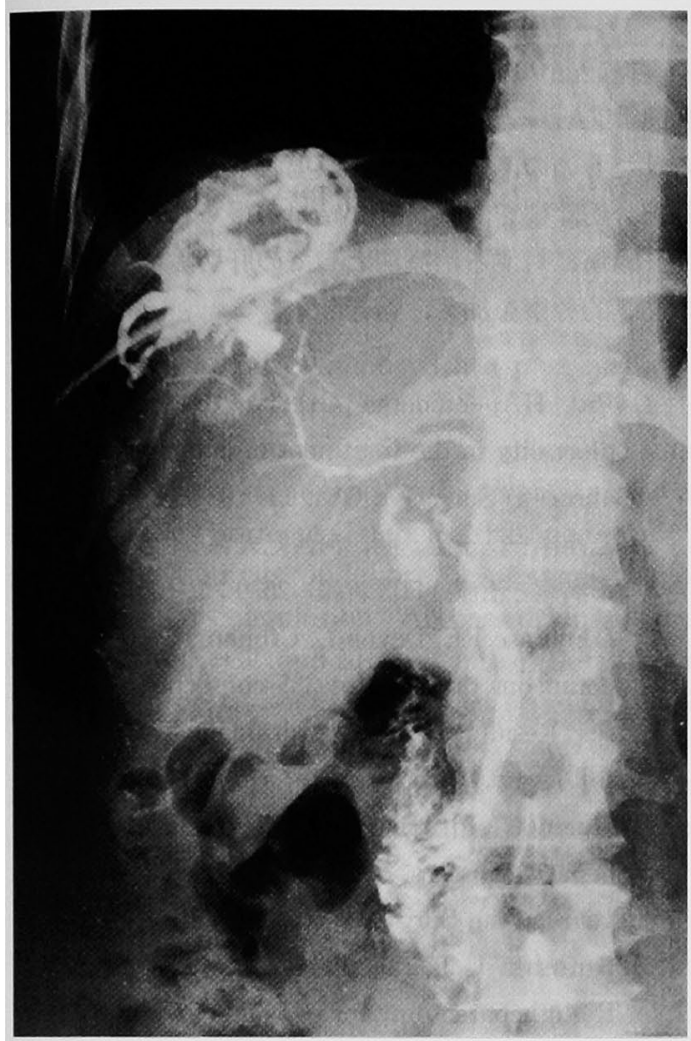

図 3 経皮経肝的肝膿演ドレナージチューブ造影（39日

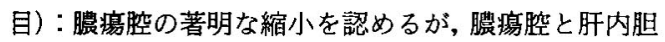
管との間に交通がみられ, 肝内胆管から総胆管まで描 出されている.胆道系に拡張や狭窄, 結石などの異常は 認めない.

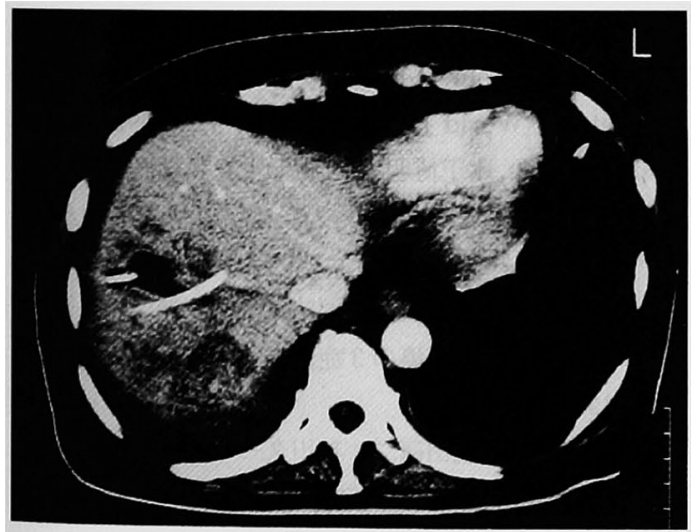

图 4 腹部 CT 像 (41日目)：肝ドーム下 S7・8に，著明 に縮小した膿瘍腔と, その周囲に境界不明瞭, 不定形の low density area の遗残を認める.

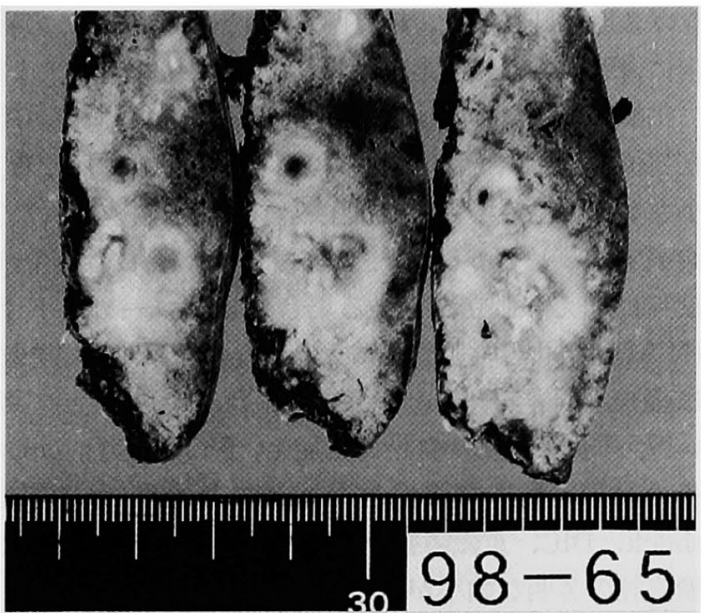

図 5 切除標本割面の肉眼所見: 黄白色の肉芽の増生を 伴う, 器質化した, 大小不同・不規則な腿湯を広筑囲に 認める。

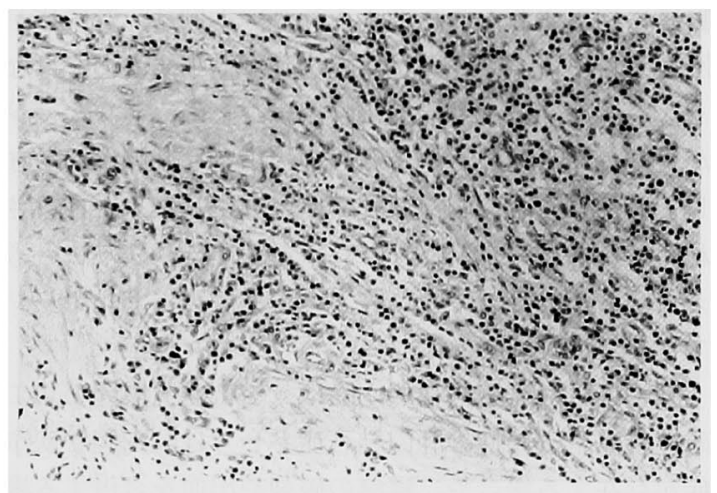

図 6 切除標本の病理組織学的所見：小円形細胞浸潤と 肝組織の破壊からなる慢性肝膿場の像を認める(HEX $100)$.

\section{考 察}

化膿性肝膿瘍は，その感染経路から，経門脈性，経 動脈性, 胆管炎性, 直達性, 外傷性, 医原性, 特発性 に分類されている な他の感染巣がなく, 胆道系にも異常がみられなかっ たことから，特発性と考えられた。なお，39日目の PTAD チューブよりの造影で胆管が描出されたが, こ れは,膿湭腔が末梢胆管に穿破したためと考えられた。

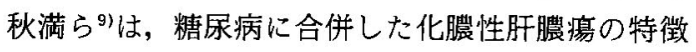
として, 特発性, 孤立性, ガス産生肝澧瘍が多く, Klebsiella が起炎菌であることを挙げている。本症例 も，基礎疾患に糖尿病があり，特発性，孤立性の巨大 
なガス産生肝膿痬で，起炎街も Klebsiella と，この報 告に合致するものであった。

化膙性肝䛜埸に対する治療法は, 肝䝢瘍の原因, 局 在部位, 大きさ, 臨床症状の程度などによって異なる。 小さな肝膿湯の場合には抗生物質の静脈内投与だけで 治痹することもあるが，腫瘍が大きい場合には抗生剤 投与に加え，孤立性である場合にはエコーガイド下 PTAD が, 化膿性胆管炎に上る多発性肝膿場の場合に は経皮経肝胆道ドレナージが施行されることが多 (20). 本例も抗生物質投与に加え, PTAD を行った, その結果，良好な排膿が得られるとともに， septic shock, DIC, 意識障害から離脱し, 全身状態の改善, 膿瘍腔の著明な縮小が得られた。

細菌性肝膿劰の治癒過程で，肉芽性変化が高度にな

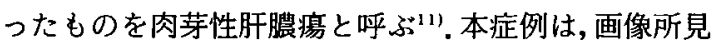
および切除肝の病理所見にて, 肝内に肉芽の增生, 器 質化した不規則な膿崵の残存を認めており，肉芽性肝 呩湯に相当するものと考えられた。本例は, 肝膿瘍が 巨大なために，同心円状に膿瑒腔が縮小するのではな く,色々な部位より治瘾に向かったため,ドレナージ が良好であったにもかかわらず，小さな肝膿烜が散在 して取り残され，肉芽性肝膿場が発生した，と推察さ れた。複数本のPTADチューブを㨉入する方法も考 えられるが，それで脹場腔すべてを確実にドレナージ できるかは疑問である.

肝膿瘍に対する外科的切除は，その発生原因として 悪性腫瘍や限局性の肝内結石症もしくは肝内胆管狭窄 症が存在する場合や，膿瘍の破裂や出血を合併する場 合に行うのが一般的である ${ }^{(2)}$. しかし, 難治性の多発性 肝膿瘍症例に対しても積極的な肝切除が試みら $れ^{5 / 6)}$, 良好な成績が報告されている. Chou ら”は, 単 発の肝膿瘍 23 例, 多発性肝膿赏 4 例に肝切除を行い, 死亡率は単発で $4.3 \%$, 多発で $0 \%$ と報告した。

われわれは, 肉芽性肝膿復の状態で, 難治と考えら れた本例に肝切除術を選択した。術後経過は合併症も なく良好で，現在まで膿崵の再発を認めていない．本 例は，経過中に菌交代を併発して扔り，保存的治療で は治痹遷延, あるいは膿湯の再燃も考えられ, 入院治 療期間はさらに長期化していたものと推察される。化 膿性肝膿瘍の治療の原則は抗生物質投与, 膿崵ドレナ ージであるが，難治となった場合には，全身状態に問 題がなければ, 肝切除術は根治が得られ, かつ入院期 間の短縮が期待できる，有効な治療法の1つであると 考えられる。
結 語

直径 $12 \mathrm{~cm}$ に扝よぶガス産生化澧性肝膿瘍に対し， 緊急 PTAD を行い, 良好な排膿, 全身状態の改善が得 られたものの，難治性の肝膿癔となった症例に対し， 肝部分切除術を試內良好な結果が得られたので，化膿 性肝脹瘍に対する治療法としての肝切除について若干 の文献的考察を加え，報告した。

\section{文 献}

1) Pitt HA, Zuidema GD: Factors influencing mortality in the treatment of pyogenic hepatic abscess. Surg Gyn Obst $140: 228-234,1975$

2）葛西洋一, 玉置 明, 河西紀夫他：化䐬性肝脹場 の病態と治療。日医新報 $2639: 10-16,1974$

3) Lambiase RE, Deyoe L, Cronan JJ, et al : Percutaneous drainage of 335 consecutive abscesses: Results of primary drainage with 1-year follow-up. Radiology $184: 167-179,1992$

4) Huang CJ, Pitt HA, Lipsett PA, et al : Pyogenic hepatic abscess. Changing trends over 42 years. Ann Surg $223: 600-609,1996$

5) Kurosaki I, Takagi K, Hatakeyama S, et al: Right hepatectomy for pyogenic liver abscesses with true multiloculatin. J Gastroenterol 32: 105-109, 1997

6) Klatchko BA, Schwartz SI:Diagnostic and therapeutic approaches to pyogenic abscess of the liver. Surg Gyn Obst 168:332-336, 1989

7) Chou FF, Sheen-Chen SM, Chen YS, et al: Single and multiple pyogenic liver abscesses: Clinical course, etiology, and results of treatment. World J Surg $21: 384-389,1997$

8）酒井克冶, 木下博明, 街 保敏：化朖性肝膿瘍 病 原菌の特徵と変遷. 肝・胆・膦 $13: 177-183$, 1986

9) 秋満忠郁, 桶田俊光, 堀田正一他：糖尿病に合併 した細菌性肝膙瘍の 3 症例。糖尿病 $36 ： 405-413$, 1993

10）吉田 博, 坂田研二, 谷川久一：特集肝膿湯, 内 科的治療とその限界. 臨消内科 $11: 1995-2003$, 1996

11）野口孝, 小倉嘉文, 水本龍二：肉苸性肝膙瘍。 肝・胆・膵 $13: 207-212,1986$

12）磯山徽, 丸山嘉一, 豊島 宏他: 特集肝膿晹, 外科的治療法。臨消内科 $11: 2005-2012 ， 1996$ 


\title{
SUCCESSFUL MANAGEMENT OF PARTIAL HEPATECTOMY AFTER PERCUTANEOUS TRANSHEPATIC DRAINAGE FOR GAS-PRODUCING PYOGENIC LIVER ABSCESS
}

\author{
Shinichi KINAMI, Masato KIRIYAMA, Hideto FUJITA, Toru II,
}

Shigeru TAKEGAWA, Shoutaro DOUBA, Yasuhiko KOJIMA and Kishichiro WATANABE* Depertments of Surgery and Pathology*, Kanazawa National Hospital

A 55-year-old woman with a past history of diabetes was admitted to the Kanazawa National Hospital complaining of high fever, general malaise, and disturbance of consciousness. The findings of ultrasonography and X-CT scan showed a gas-producing pyogenic abscess approximately $12 \mathrm{~cm}$ in diameter in the right lobe of the liver. Immediately after diagnosis, percutaneous transhepatic abscess drainage was performed under ultrasonographic guidance. Klebsiella was detected by culture of drained pus. The findings of laboratory examinations showed dehydration, septic shock, and disseminated intravascular coagulation. Abscess drainage was effective, however, a granulomatous liver abscess was detected by X-CT and MRI in spite of the reduction of the abscess cavity. On hospital day 68 , the patient underwent partial hepatectomy of segment 7 and 8 , because it seemed unlikely that the abscess would heal completely by drainage alone. Thereafter, the patient recovered uneventfully and has been leading a healthy life without recurrence. Hepatic resection after adequate drainage is considered an effective procedure for cases of intractable pyogenic liver abscess. 